Tarcisio Torres Silva

Pontifícia Universidade Católica de Campinas, Campinas, SP, Brasil

\title{
A biopolítica do corpo feminino em estratégias contemporâneas de ativismo digital
}

Resumo: Neste trabalho, observamos a utilização da imagem do corpo feminino como uma estratégia recorrente em ações ativistas em diferentes partes do mundo. Os elementos estéticopolíticos do corpo, historicamente utilizados pelas artes, tais como o nu, a dor, o erotismo e a identidade (ou o anonimato) são reconduzidos para um projeto de cultura ativa e participativa dentro das redes de comunicação digital. Nossa análise insere-se no campo da biopolítica e faz uso de três exemplos recentes: os autorretratos da egípcia Aliaa Magda Elmahdy e as ações dos coletivos Pussy Riot (Rússia) e Femen (Ucrânia).

Palovras-chave: corpo feminino; biopolítica; ativismo digital; Pussy Riot; Femen.

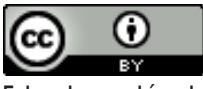

Esta obra está sob licença Creative Commons.

\section{Introdução}

Na análise que se seguirá, observamos que o corpo feminino aparece como um instrumento bastante utilizado como forma de chamar a atenção para causas que mesclam questões políticas locais e globais com o fato de ser mulher no mundo contemporâneo. Esta relação entre o corpo feminino e os atos de resistência não é casual, pois há alguns fatores que aproximam essas duas instâncias, como nos coloca Marvin Carlson (2009). Segundo o autor, a performance política que aparece a partir dos anos 60 , nos EUA, vai ter grande participação de mulheres interessadas pelas estratégias oferecidas pela performance e o teatro de rua. Ele investiga os sentidos que podem ser extraídos da posição da mulher na performance e mostra que há uma condição essencial nela mesma, que é a tentativa de quebrar a narrativa social patriarcal em que o homem é sempre visto como sujeito e a mulher como objeto, ou, ainda, um ser passivo ou coadjuvante (relação dicotômica). Fazendo referência à pensadora Júlia Kristeva, o autor vai dizer que: 


\begin{abstract}
A performance física tem oferecido uma possibilidade para as mulheres escaparem do que Kristeva chamou de linguagem discursiva lógica e "simbólica" do pai para a linguagem poética, física e "semiótica" da mãe. A utilização do corpo na performance pode, assim, fornecer uma alternativa para a própria ordem simbólica da linguagem que, segundo muitas teóricas feministas afirmam, não fornece abertura para a representação da mulher (CARLSON, 2009, p. 191-192).
\end{abstract}

Há, portanto, uma linha discursiva que une os exemplos que iremos abordar abaixo com a própria história da performance e do feminismo. Não é nosso intuito nos aprofundarmos sobre os diversos lados desse debate, pois se trata de um tema complexo e que merece o cuidado necessário quando abordado academicamente. Porém, vale ressaltar que lá, como agora, a estratégia do uso do corpo feminino não era um consenso entre as feministas.

A discussão proposta por Carlson (2009) mostra que havia uma preocupação se a exploração desse corpo poderia, na verdade, reforçar as categorias de representação já presentes na sociedade. Como mostra Lucila Scavone (2004), as bandeiras levantadas pelo feminismo ao longo das últimas décadas direcionam-se a desbancar teorias biodeterministas que tratam da desigualdade entre os sexos a partir da sua própria natureza, desconsiderando os fatores socioculturais que ocasionam as reais condições de opressão. Assim, o corpo performático feminino aparece dentro de um esforço de causar curtos-circuitos que o retiram da lógica dicotômica, biodeterminada, para criar novas formas de ser, sentir e representar.

Os três casos que iremos abordar - as fotografias da egípcia Aliaa Magda Elmahdy, e as ações dos grupos Pussy Riot (Rússia) e o Femen (Ucrânia) - são exemplos de performances femininas que fizeram uso de mídias digitais como parte de suas estratégias. Veremos que estes exemplos politizam o corpo feminino nas redes digitais de comunicação ao mesmo tempo em que se aproximam de referências anteriores. Será, portanto, nossa intenção, mencionar, também, algumas dessas referências durante nossa abordagem. Assim agindo, faremos jus à ligação com os movimentos feministas dos anos 60 que aqui apontamos e outros movimentos que ainda serão citados. Nossa intenção, contudo, não é observar correlações entre gerações, mas mostrar outros elementos que podem ser problematizados considerando a condição social, política e tecnológica do mundo contemporâneo. Nossa opção é, portanto, mais entender os possíveis diálogos existentes entre os exemplos contemporâneos do que conectá-los a determinadas frentes do movimento feminista. 
' Forma de marcação de posts no Twitter, o que facilita a busca dentro do site.
${ }^{2} \mathrm{O}$ grupo liberal ao qual foi ligado - nome de Aliaa chama-se "Movimento 6 de Abril", envolvido diretamente na organização dos protestos da praça Tahrir, em 2011. A mobilização egípcia fez parte do conjunto de levantes populares do norte da África e Oriente Médio entre 2010 e 2011 que ficou conhecido como "Primavera Árabe".

${ }^{3}$ Texto de até 140 caracteres postado no Twitter.

${ }^{4}$ Originário do livro de Richard Dawkins (2006), o termo meme refere-se a um fragmento de informação que, em função do seu potencial inerente, é capaz de autopropagar-se. Dawkins faz alusão aos genes para tratar certos signos como se fossem unidades básicas de comunicação que se reproduzem nas redes de comunicação. Nas mídias digitais, os memes podem ser representados por notícias, imagens e vídeos virais de alto impacto.

${ }^{5}$ Diversas dessas imagens podem ser vistas no post original da foto de Aliaa. Disponível em: http:// arebelsdiary.blogspot.com.br/ 2011/10/nude-art 2515. html. Acesso em: 19 jan. 2016.

${ }^{6}$ Trecho original: "the photo is an expression of my being and I see the human body as the best artistic representation of that. I took the photo myself using a timer on my personal camera. The powerful colors black and red inspire me".

\section{Aliaa Magda Elmahdy}

Com uma foto, essa egípcia, então com 20 anos, conseguiu transformar seu corpo em um instrumento político que serviu a diferentes propósitos. Postada, inicialmente, em seu blog (ELMAHDY, 2011), em outubro de 2011, a foto da estudante nua, usando apenas sapato vermelho, meia-calça e uma fita vermelha no cabelo, foi, posteriormente, divulgada no Twitter, atrelada à hashtag' \#nudephotorevolutionary, de onde adquiriu efeito viral imediato.

O protesto de Aliaa ficou conhecido por diversas razões. A primeira delas é a sua nacionalidade (egípcia). O país é majoritariamente muçulmano e a nudez feminina não é bem vista aos olhos da maioria da população que vive em um país onde é comum o uso da burca e outros trajes que resguardam o corpo feminino. $O$ ato, então, pode ser traduzido para alguns como uma atitude corajosa e, para outros, como uma ofensa aos princípios da religião muçulmana que vigora no país.

Outra razão é que a data da postagem da foto coincidiu com a véspera das primeiras eleições legislativas egípcias depois da queda do ditador Hosni Mubarak, realizadas em novembro de 2011 . A fotografia da jovem nua foi motivo de acusações dos conservadores contra os liberais no Egito, pois os primeiros entendiam que Aliaa era integrante do grupo dos segundos, como indica Maggie Michael (2011). Temendo que tal associação pudesse influenciar negativa mente o resultado das eleições, os egípcios liberais publicaram uma nota, afirmando que a jovem não fazia parte do grupo. ${ }^{2}$

Finalmente, em função, provavelmente, das duas primeiras razões, a foto de Aliaa teve efeito viral de grandes proporções na internet. O tweet ${ }^{3}$ com sua foto foi visualizado mais de 1 milhão de vezes e sua atitude se dividiu entre seus apoiadores e aqueles que a condenavam. A imagem em si transformou-se em um meme ${ }^{4}$ que gerou uma série de releituras, colagens e associações ${ }^{5}$ com o intuito de manifestar apoio à jovem.

Em entrevista ao site da CNN, Aliaa explica que não tem vergonha de ser mulher em uma sociedade em que a mulher é molestada diariamente. Quando perguntada sobre os motivos que a levaram a produzir a imagem, ela diz:

"a foto é uma expressão do meu ser e eu vejo o corpo humano como a melhor representação artística disso. Eu mesma tirei a foto usando o timer da minha câmera pessoal. O poder das cores preta e vermelha me inspira" (ELMAHDY, 2012 [tradução própria]). ${ }^{6}$

A repercussão da fotografia provocou um debate sobre a condição da mulher nos países muçulmanos e a 
${ }^{7} \mathrm{Na}$ era do capital globalizado $e$ de impérios sem território, os corpos surgiram como o luga singular de resistência ao poder da violência suicida ao redor do globo a jovens mulheres expondo seus corpos para chocar e intimidar de uma maneira diferente. [Tradução própria] liberdade de expressão ou de exibição do corpo que parece ali faltar-ao menos do ponto de vista dos países do ocidente. Porém, como colocado por Hamid Dabashi (2012) ao tratar do mesmo caso, não se trata da limitação da exposição do corpo feminino nos países muçulmanos, mas, sim, de uma condição de escolha que deve ser dada aos indivíduos em países considerados democráticos. Como contraposição ao pensamento inicial, o autor cita o caso da França, que proíbe o uso da burca em espaços públicos no país. Menos conhecido que o caso de Aliaa, este exemplo lembra que a lei francesa também gerou protestos no país, com mulheres indo às ruas exigindo que lhes fosse permitido o uso da indumentária.

Contrabalanceando a discussão com esse importante elemento do livre arbítrio do uso do corpo, Dabashi (2012) segue em uma argumentação na qual tenta entender os diversos protestos recentes em que se nota a utilização do corpo como instrumento de protesto político. Similar em termos de valores e repercussão, o autor cita, também, o caso da atriz iraniana Golshifteh Farahani, residente hoje na França, e que foi impedida de voltar ao seu país por posar seminua para a revista francesa Madame Le Figaro e por uma participação no vídeo Corps et Âmes (MONDINO, 2012), em que expõe um de seus seios. O que o autor evidencia é a singularidade do corpo como forma de resistência no mundo contemporâneo:

In the age of globalised capital and aterritorial empires, bodies have emerged as the singular site of resistance to power - from suicidal violence around the globe to young women exposing their bodies to shock and awe of a different sort (DABASHI, 2012).?

Dabashi lembra, assim, que a exposição desses corpos se dá em um mundo sob a ordem do capitalismo global em que impérios sem territórios superam a concepção do Estado-nação. Esse deslocamento do ordenamento do poder é, para Giorgio Agamben (2007), resultado de uma ruptura em que é possível entender também a forma como o biológico ganha ênfase na política atual.

Se, antes, o Estado podia ser entendido a partir de um tripé composto por três itens: o território, o ordenamento e o nascimento (o que dá a condição de nacionalidade do sujeito), com a relativização dos dois primeiros fatores, há uma ênfase no nascimento do indivíduo. Tal fato colabora para o entendimento da política sob o ponto de vista físicobiológico em torno do qual gira o debate sobre a ação de Aliaa, ou seja, o que fere, na imagem, é o fato de que a mulher ali representada está vinculada pelo nascimento ao estado muçulmano egípcio. 
${ }^{8}$ A redução sistemática da vida à biopolítica é completamente feita sob o radar da publicidade instantânea que acompanha atos amplamente divulgados, tais como os de Elmahdy ou Farahani. Quando Agamben teorizou os contornos do homo sacer - da redução da pessoa civil à "vida nua" na sociedade do espetáculo e no "estado de exceção" que se tornou a regra, ele já tinha levado a cabo a transformação das sociedades civis em campos como o nomos do moderno. O fato de o Movimento Verde no Irã ou a Primavera Árabe no mundo árabe estarem remodelando 0 mapa moral da região não significa que nós tenhamos superado esse espectro assustador. [Tradução própria]
O corpo nu da jovem passa a confrontar um território (o Egito) e as instâncias de poder ali presentes, sejam grupos políticos ou religiosos. Projetado em nível global por meio das tecnologias de comunicação, a imagem transmuta em sentidos, mas permanece a contraposição entre o corpo nu, o ser vivente que se quer livre, e as esferas de dominação que se pretende provocar com sua exposição. Realizada de forma amadora, a fotografia intensifica a politização da vida privada da maneira como observamos.

A visão de Dabashi (2012) colabora, também, para entendermos o caso do ponto de vista da biopolítica ao considerar o papel que as tecnologias de comunicação exerceram durante os eventos por ele citados. Para o autor, a instantaneidade com que esses casos vieram à tona contribui para entendermos a condição biopolítica em que se encontra o indivíduo no mundo contemporâneo.

The systematic reduction of life to biopolitics is done entirely beneath the radar of the instantaneous publicities that accompany such widely publicised acts as those of Elmahdy or Farahani. When Agamben theorised the contours of the homo sacer - of the reduction of the civil persona to "bare life" in the society of spectacle and in a "state of exception" that has become the rule, he had already seen through the transformation of civic societies into camps as the nomos of the modern. The fact that the Green Movement in Iran or the Arab Spring in the Arab world is recasting the moral map of the region does not mean we have overcome that frightful spectre (DABASHI, 2012). ${ }^{8}$

Considerando, assim, o raciocínio proposto por Dabashi (2012), é muito provável que, antes da inclusão do mundo árabe nas redes digitais de comunicação, outros casos desse tipo permanecessem isolados dentro de, no máximo, uma crise local, sem a divulgação massiva global que agora testemunhamos. Porém, poderíamos, ainda assim, constatar a politização da vida sendo feita por meio da exposição do corpo, pois a mesma já é praticada há bastante tempo, como bem nos mostra Agamben (2007). Com as tecnologias de comunicação, no entanto, o local transforma-se em global, ferindo leis e regras regionais que não têm espaço no redimensionamento que a imagem ganha com a velocidade de repercussão nas redes.

Em pouco tempo, novas interpretações são dadas tanto por usuários anônimos, como pela mídia corporativa internacional. Os debates, muitas vezes, fogem da questão original ou, como também notamos, ocorre um esvaziamento da problemática inicial, restando apenas na imagem (ou no meme) frases de efeito ligadas a ela. Nos diversos memes 


\begin{abstract}
${ }^{9}$ Neste caso, o design escolhido para o meme faz referência direta ao trabalho de mesmo título da artista americana Barbara Kruger, de 1989. Produzido originalmente para enfatizar o direito de escolha das mulheres em uma marcha em Washington, o cartaz ganhou contornos mais universalizantes. Ao comparar o corpo feminino a um campo de batalha, o cartaz lembra que algumas decisões políticas podem afetá-lo diretamente. Por exemplo, leis referentes ao aborto.
\end{abstract}

feitos com a fotografia de Aliaa, lemos frases como "freedom and the revol(love)ution" ou "your body is a battle ground". 9 O corpo transforma-se em instrumento de politização, mas como se nota nessas frases-exemplo, trata-se de uma questão de "liberdade" e "individualização" que, como colocado por Agamben (2007) e também Nikolas Rose (2001), são valores que fazem parte da politização da vida nua.

As demandas emergentes contemporâneas que expressam o "direito à vida" mostram a vulnerabilidade em que se encontram os indivíduos politicamente, pois seus corpos biológicos encontram-se entrelaçados com seus anseios políticos em uma mesma zona indiscernível. É como se a condição à "vida" valesse, por si só, pela plenitude da existência do homem como animal político. A descida do entendimento da política ao nível biológico nos torna mais individualistas e desprovidos de compartilhamento comum, já que, na base, o que interessa é a "vida" (ou o corpo, a beleza, a saúde, a segurança, a independência sexual) de cada um.

\section{Pussy Riot}

O Pussy Rioté um grupo de punk rock feminista russo que foi formado em outubro de 2011 . Surgiu em meio à crise política do país, que previa a eleição do atual presidente Vladimir Putin, que atuava então como premiê. O país vivia a eminência de sua volta ao poder e muitos cidadãos rejeitavam a ideia, em função das acusações sobre a atuação política de Putin, que incluíam corrupção, monopólio governista dos meios de comunicação, repressão a protestos públicos etc.

O grupo decidiu protestar por oposição ao governo de Putin, acusado, também, de limitar os direitos civis da população. A restrição de direitos feria igualmente os princípios feministas, pois algumas sanções eram direcionadas às mulheres, como, por exemplo, medidas de restrição ao aborto legal. Em entrevista ${ }^{10}$ do Pussy Riot a Henry Langston, do site Vice, entendemos que outras causas defendidas pelo grupo incluem a luta pelos direitos de gênero e LGBT (Lésbicas, Gays, Bissexuais, Travestis, Transexuais e Transgêneros), o combate à dominação masculina nas áreas do discurso público e à falta de viés político na cena artística e cultural (LANGSTON, 2012).

A atuação do grupo acontece por meio de performances de suas músicas em espaços públicos, de maneira rápida e inusitada, similares a flashmobs. ${ }^{11}$ Alguns dos lugares são estrategicamente selecionados por representarem a instância de poder sendo questionada. Entre os "palcos" utilizados pela banda, foram escolhidas 
${ }^{12}$ A KGB (Comitê de Segurança do Estado) era o principal órgão de serviços secretos da União Soviética. Funcionou entre 1954 e 1991.

\footnotetext{
${ }^{13}$ Tal sinergia está ligada ao fato de ambos os grupos fazerem parte de uma mesma cena ativista no país, mas, também, pelo fato de que duas das integrantes do Pussy Riot, Nadezhda Tolokonnikova e Yekaterina Samutsevich, serem também integrantes do Voina.
}

uma estação de metrô, o telhado de um centro de detenção em Moscou, a praça mais famosa da Rússia (a Praça Vermelha) e o interior de uma igreja. As músicas têm letras agressivas e alvos pontuais, dos quais destacamos o governo de Vladimir Putin, a igreja Ortodoxa (que teria relações próximas com esse governo), a $K G B^{12}$ e o machismo na Rússia.

Como nos coloca Laura Barton (2012), o Pussy Riot surge em meio a uma geração de ativistas que têm realizado diferentes protestos pela Rússia, demonstrando sua insatisfação política, alguns atuando, também, de forma bastante radical nos últimos anos. Entre eles, destaca-se o Voina, grupo de artistas russos atuante desde 2005 que realiza suas ações em espaços públicos. Suas estratégias de ataque político envolvem intervenções em prédios e vias públicas, vandalismo, furtos em supermercados (shoplifting) e performances. Dentre as ações mais significativas, estão uma orgia performática no Museu Biológico Estatal Timiryazev (Coletivo Voina, 2008) e o grafite de um imenso pênis de 65 metros de altura em uma ponte levadiça em São Petersburgo, localizada em frente ao FSB (Serviço de Segurança Federal), sucessor da KGB (Coletivo Voina, 2010). Assim, percebemos que há uma movimentação na Rússia que localiza as ações do Pussy Riot não como ações isoladas de um grupo feminista, mas inseridas dentro de uma tradição ativista russa movida por descontentamento político. As ações anteriores realizadas pelo coletivo Voina são bastante representativas para entendermos o tipo de atenção política requerida pelas integrantes do Pussy Riot. Observamos, em ambos os grupos, ${ }^{13}$ o gosto pela radicalidade nas ações, particularmente notável por acontecerem em um país cuja repressão e prisão de ativistas é uma realidade. É evidente, também, a opção pela performance em espaços públicos, a importância da localização da ação performática, com destaque para intervenções em prédios e espaços públicos significativos, o ataque a instituições (Igreja Ortodoxa) e organizações públicas (prisão, polícia, comitês) e, finalmente, um apreço pela diversidade.

No caso do Pussy Riot, a estratégia que fez com que - grupo ganhasse a atenção pelo mundo se deu, inicialmente, por meio de suas ações performáticas. Nas ações realizadas exclusivamente por mulheres, suas integrantes escolheram, para aparecer publicamente, vestidos bastante coloridos e um elemento estético que serviu tanto para proteger suas identidades como criar uma identificação para o grupo: a balaclava, igualmente colorida.

Entre as ações do grupo, duas se destacam pela projeção midiática que conseguiram. A primeira foi a 
${ }^{14}$ Letra e tradução em inglês disponíveis em: http://russmus.net/ song/12000.

${ }^{15}$ Uma versão da letra para o inglês é oferecida por Carol Rumens, do jornal britânico The Guardian.

\begin{abstract}
${ }^{16} \mathrm{Em} 17$ de agosto de 2012, as três integrantes foram condenadas a dois anos de prisão por vandalismo e ódio religioso. Em 10 de outubro do mesmo ano, uma das acusadas, Yekaterina Samutsevich, foi libertada após pedido de recurso. As duas outras integrantes cumpriram pena até dezembro de 2013, quando foram beneficiadas por lei de anistia do governo russo.

${ }^{17} \mathrm{O}$ documentário Pussy Riot: a punk prayer, de Mike Lerner e Maxim Pozdorovkin, lançado em 2013, também auxiliou na projeção mundial do nome do grupo.
\end{abstract}

performance na Praça Vermelha (PUSSY Riot, 2012), em janeiro de 2012, quando tocaram a música Revolt in Russia, Putin's got scared (PUSSY RIOT, 201 1), ${ }^{14}$ tendo à sua frente a catedral de São Basílio e, do lado oposto, o Kremlin. A ação foi rápida, sob o clima severo de inverno em Moscou, mas devidamente registrada pela mídia corporativa e também pelo próprio grupo.

A outra ação se deu na Catedral de Cristo Salvador (PUSSY Riot, 2012), em 21 de fevereiro do mesmo ano. Desta vez, a música performada foi Punk Prayer, ${ }^{15}$ que critica o apoio da igreja ortodoxa a Vladimir Putin. A ação, em si, é muito rápida, dura cerca de um minuto, mas é devidamente registrada de vários ângulos por cinegrafistas e fotógrafos presentes no local. Durante a performance, cinco (5) integrantes do grupo invadem o altar da igreja, colocam a música para tocar e encenam movimentos que lembram ora uma dança punk, ora um fiel ajoelhado e fazendo o sinal da cruz. A performance presencial obteve o olhar testemunhal de poucas pessoas, mas o que ocorreu depois dela foi muito em função do vídeo (editado e postado na internet, produzido com o objetivo inicial de ser o videoclipe da música). Dias depois da performance, exatamente um dia após a eleição de Putin, duas das integrantes foram presas, seguidas de mais uma. O que se sucedeu em seguida foi um debate acalorado em blogs, redes sociais e, também, na mídia corporativa a respeito do julgamento de Nadezhda Tolokonnikova, Yekaterina Samutsevich e Maria Alyokhina, ${ }^{16}$ os limites da liberdade de expressão na Rússia e as relações entre a Igreja Ortodoxa e o governo russo.

Os dois eventos, principalmente o segundo, fizeram com que o grupo ficasse mundialmente famoso. ${ }^{17} \mathrm{Em}$ termos gerais, resumem-se ao que expomos acima. A opção estética multicolorida de apresentação do grupo, sua vertente feminista, as letras 'punk' de cunho crítico, o registro e a edição de imagens amadoras e o compartilhamento pelas mídias digitais são características do grupo. O que nos interessa apontar, aqui, pode ser resumido nesta pergunta: qual a razão desse grupo, em particular, ter se destacado com a ação ativista?

As razões podem estar justamente nessa conjunção de fatores que o grupo conseguiu unir. A começar pela improbabilidade dos elementos presentes nas imagens ligadas à ação em frente ao Kremlin. Elementos completamente díspares (o prédio símbolo do poder na Rússia, mulheres em roupas coloridas, a agressividade da música punk e um clima severo de neve que impediria o uso daquelas vestimentas). Na idiossincrasia da cena nasce o interesse midiático pelo tema. Porém, a junção de

746 Estudos Feministas, Florianópolis, 24(3): 739-759, setembro-dezembro/2016 
elementos por si só não basta para entendermos o fenômeno por completo. Para tanto, gostaríamos de apontar algumas características das imagens ligadas à banda que as tornam potencialmente eficazes do ponto de vista da construção de uma narrativa criada pelo grupo, compartilhada em rede e alimentada pelas mídias corporativas.

A ação do Pussy Riot é iconográfica por nos remeter a imagens de uma cultura pop compartilhada por todo o mundo. Em primeiro lugar, temos a balaclava. O adereço está associado a uma cultura imagética ligada ao clandestino, à criminalidade e aos atentados terroristas. Além disso, funciona como um elemento que esconde a identidade das integrantes, preservando sua integridade e protegendo-as de perseguições políticas do governo russo.

Em diversas entrevistas, as integrantes do grupo aparecem com a balaclava e fazem uso de nomes fictícios. Com o processo da ação na Catedral de Cristo Salvador, a identidade aparece de forma brutal em função da alta exposição midiática das três acusadas. Porém, outra questão se coloca. Há dúvidas de onde estavam as duas integrantes que permaneceram presas ou, até mesmo, se realmente participaram da ação, já que não é possível reconhecê-las nos vídeos. Assim, o que é interessante notar é que a ação repressiva do governo russo se dá em função de uma ideia, mais do que da ação em si, não importando o ato individual, mas o coletivo. Finalmente, em função do colorido das vestimentas, também trazem à tona a memória das figuras dos super-heróis de histórias em quadrinhos que, da mesma forma, mantêm "identidades duplas".

A utilização de máscaras faz referência, ainda, ao grupo feminista de artistas americanas, o Guerrilla Girls ( 2016), que se tornou conhecido nos anos 80 por suas ações que questionavam a pouca participação das mulheres no mercado das artes e nos museus. Sempre que apareceriam em público, suas integrantes utilizavam máscaras de gorilas que tinham como objetivo preservar a identidade das participantes perante o mercado artístico da época. André Mesquita (2008) explica o propósito do grupo:

O Guerrilla Girls procurou "reinventar o feminismo" apresentando-se como um grupo anônimo formado por artistas, críticas de arte e ativistas. Desde então, as integrantes do coletivo aparecem publicamente vestidas com máscaras de gorila e usam pseudônimos de artistas famosas (...) para proteger suas identidades e despersonalizar suas demandas, que buscam conscientizar as pessoas sobre a ideia de um projeto político que examine as estruturas contraditórias da produção cultural (p. 117). 
${ }^{18} \mathrm{O}$ manifesto original do movimento está disponível em: http:// onewarart.org/riot_grrrl_manifesto. $\mathrm{htm}$.

19 "Do It Yourself" ou "Faça você mesmo(a)". Cultura alternativa que propõe a substituição de compras de objetos prontos pela produção criativa e independente feita por meio do artesanato e das artes.

${ }^{20}$ Trecho original: "also embody a shift in culture that echoes the DIY culture that flourished in the Seattle and Olympia areas of Washington in the early 90 s fanzines, garage punk bands, a tone of wild irreverence and $a$ wish to question tradition".

\footnotetext{
${ }^{21}$ Trecho original: "the memes that run through global activism networks also travel well because they ride on cross-culture carries produced by globalization itself: brands, movies, music, celebrities".
}

É evidente, também, a menção do Pussy Riot à cultura punk, mas, sobretudo, ao movimento feminista americano do início dos anos 90, o Riot Grrrl, citado como uma das fontes de inspiração do grupo (LANGSTON, 2012). Segundo Barton (2012), o Riot Grrrl disseminou-se como uma subcultura nos Estados Unidos ligada, principalmente, à cultura musical das bandas e à cultura escrita, por meio da produção de fanzines (RIOT Grrrl, 1991). ${ }^{18}$ Entre as causas do movimento, estavam a legalização do aborto, o empoderamento feminino e a igualdade salarial entre sexos, além do combate à violência doméstica e o patriarcalismo.

O Riot Grrrl também estava conectado a uma cultura amadora independente, cuja dinâmica proporcionava a livre expressão, similar ao que parece acontecer, agora, na Rússia. Como nos coloca Barton (2012), a banda Pussy Riot "também incorporou uma mudança na cultura que ecoa a cultura $D / Y^{19}$ que floresceu nas áreas de Seatlle e Olympia, de Washington, no começo dos anos 90 - fanzines, bandas punk de garagem, um tom de irreverência selvagem e um desejo de questionar a tradição" (BARTON, 2012 [tradução própria]). ${ }^{20}$

Essas referências que se somam à atuação do Pussy Riot têm muito a ver com o aumento de troca de informação através das redes de comunicação, o que, por sua vez, faz com que cresça, também, o sentimento mundial de compartilhamento de uma cultura global. Valores, medos e motivações são divididos por meio de signos no ciberespaço. Esse movimento colabora com o aparecimento de ações como essas, que defendem valores locais, mas não necessariamente nacionais. Ao invés de clamarem por um ícone político ou levantarem os braços ao som do hino nacional, os ativistas escolhem chamar a atenção para suas causas por meio de estratégias mais eficazes, como observamos nesse caso.

W. Lance Bennett (2003) também acredita que o ativismo está ficando mais conectado a outros tipos de cultura. Ele propõe que a resistência está se tornando menos nacionalista e mais baseada em escolhas individuais e redes sociais. Imersos em fluxos de informação criados por mídias digitais pessoais e redes sociais, os memes, trafegando por essas redes digitais, podem interferir no estilo de vida da audiência. O mesmo está acontecendo com as redes ativistas. Bennett argumenta que

"os memes que correm através das redes de ativismo global também viajam bem porque eles seguem sobre trajetórias de cultura cruzada, produzidas pela própria globalização: marcas, filmes, música, celebridades" (BENNETT, 2003, p. 32 [tradução própria]). ${ }^{21}$ 
${ }^{22}$ Post é o termo para a publicação de textos em blogs. É indicado por data e hora de publicação.

\begin{abstract}
${ }^{23}$ Eu já assisti algumas vezes ao vídeo da banda punk de protesto feminista Pussy Riot performando na Praça Vermelha e a cada vez que eu o vejo, eu começo a me sentir um pouco emotiva. Elas pulam e gritam em suas máscaras de esqui cor de arco-íris, vestidos vivos e calças justas, punhos levantados, braços expostos no meio do inverno em Moscou. $\mathrm{O}$ Kremlin e a Catedral de São Basílio, grandes símbolos de séculos de poder russo-que mudaram muitas vezes, mas sempre repressivos agigantam-se ao alto da cena. [Tradução própria]
\end{abstract}

É fato que a essa cultura pop presente nas ações do Pussy Riot são somados elementos que remetem ao poder e à tradição russas, o que gera um estranhamento inicial, mas que também proporciona fruição estética ao espectador. A atmosfera do vídeo da Praça Vermelha - citado anteriormente - é bem descrita neste depoimento encontrado em um post $t^{22}$ sobre o grupo:

I've watched the video of the Russian feminist protest punk band Pussy Riot performing in Red Square quite a few times now, and every time I see it I start to feel a little emotional. They jump and scream in their rainbow colored ski-masks, bright dresses and tights, fists in the air, bare-armed in the middle of winter in Moscow. The Kremlin and St. Basil's Cathedral, great symbols of centuries of Russian power - many times changed, but always repressive - loom overhead (Helen STUHRROMMEREIM, 2012). ${ }^{23}$

Acreditamos que o conjunto de fatores apontados acima, atrelado à estética amadora presente no modus operandi do grupo, assim como nos vídeos de suas ações, está ligado ao prazer de fruição relatado pela espectadora acima. Há uma confluência de fatores que colaboram para que o sujeito comum (o amador) vibre e torça ao ir de encontro com o objeto estético que lhe é oferecido. Não propomos, aqui, que as ações do grupo sejam apoiadas de forma unânime, pois sabemos que tanto na Rússia como pelo mundo, as opiniões sobre elas são divergentes. O mais relevante é notarmos as reações que essas ações provocam, sejam elas positivas ou negativas. O radicalismo do Voina estava amparado em uma biopolítica que propunha, por meio da performance do corpo em situações de risco e limite, um afrontamento com os dispositivos de disciplina e controle do corpo. É o mesmo que acontece com o Pussy Riot, que adiciona ao seu radicalismo a cor vibrante de suas vestimentas e a potência feminina e juvenil, o que torna as ações mais chamativas para os olhares externos.

Por meio dessa atitude, observamos um debate público que parte de uma produção amadora, que navega pelas mídias sociais e corporativas e atinge as instituições, particularmente, neste caso, a lgreja e os órgãos ligados ao governo russo. Há uma construção de significados que parte do amador que se arrasta pela multidão, transformando o objeto estético inicial em uma chave para a produção biopolítica que, como observamos aqui, de fato colocou as instituições disciplinares e de controle mencionadas por Michael Foucault $(1988,2008)$ sob uma óptica crítica. A forma como os significados desses elementos fundamentais de um Estado milenar e tradicionalista são deturpados por meio das invasões dos prédios e a ironização de seus 
métodos nas letras em performances do grupo mostram o potencial efetivo que as imagens amadoras podem provocar.

\section{Femen}

O terceiro exemplo trata-se do grupo Femen. Ele nasceu na Ucrânia, no ano de 2008, com o intuito inicial de protestar contra o turismo sexual e a prostituição do país. A partir do final de 2009, foi adicionada ao grupo a estratégia de exibição pública de lindas mulheres com os seios à mostra e a utilização de frases curtas reproduzidas em cartazes, pintadas nos corpos das manifestantes ou pronunciadas por meio de gritos imperativos.

A opção por uma ação mais eficazmente performática pelo grupo tem como resultado a geração de atos esteticamente significativos que, inicialmente, foram explorados como forma de chamar a atenção da grande mídia. Como nos coloca Jessica Zychowicz (201 1), a partir de 2010, o modelo inicial proposto mudou, tanto no que diz respeito às causas, como na maneira de lidar com as mídias. Algumas das novas causas giravam em torno da mulher; outras, não, necessariamente. Chernobyl, a repressão da mulher islâmica e a Eurocopa são exemplos dessas novas causas assinadas pelo grupo. Há registros, também, de participações em eventos anticapitalistas. Em depoimentos mais recentes da líder do grupo, Anna Hutsol, e outras participantes, é possível observá-las definindo o grupo como "neofeminista". Ao assim procederem, elas aparentemente se esquivam de tomar parte em discussões mais aprofundadas da academia, que tende a se dividir entre apoiadores e segregadores do Femen. Entre os que criticam o grupo, existe a opinião de que as ações colocam o corpo da mulher numa condição sexualizada em excesso para receber como moeda de troca a atenção da mídia. No julgamento dessas pessoas, o grupo, ao invés de convidar para um novo olhar sobre a mulher na sociedade, reforça sua objetificação. Segundo Jessica Zychowicz, porém, entre aqueles que apoiam o grupo na Ucrânia, entende-se que o corpo feminino é uma ferramenta de resistência, "posando para uma audiência consumista a imagem denegrida do consumo daquela audiência" (2011, p. 18 [Tradução própria])..$^{24}$

Com relação à presença na mídia, o Femen começa, coniginal: "posturing for denigrated image of that audience's consumption".

a partir de 2010, a transformar suas performances em atos que ganham vida própria por meio das redes sociais. O grupo passa a explorar o poder de compartilhamento e difusão da internet, criando conteúdos específicos que são postados online. Desses conteúdos, destacam-se fotos e vídeos produzi- 
dos a partir de suas performances. Esse entendimento do grupo acerca da sobreposição das mídias fez com que suas ações se tornassem um evento plenamente coberto, tanto pela mídia oficial como por amadores. Neste último caso, inclui-se o registro premeditado pelas integrantes do grupo durante as performances.

Numa ação típica, o Femen avisa a grande mídia sobre a data e o local onde irá acontecer a ação. Suas participantes organizam-se previamente, com a pintura no corpo, dirigem-se ao local escolhido, tiram suas blusas e iniciam a performance, enquanto os jornalistas, posicionados, registram os acontecimentos. Quando a ação é pouco abusiva, ou seja, não há riscos de maiores consequências penais, as participantes esperam a chegada da polícia, que, ao tentar agarrá-las, propicia involuntariamente a produção de imagens que remetem a um vasto leque da iconografia ocidental, incluindo o fetiche dos elementos ali combinados: a farda (como representação do poder e do masculino), as lindas mulheres seminuas em situação de violência (mais teatralizada do que real, na maioria dos casos) e a corrupção de espaços sacralizados, como igrejas, praças e prédios públicos. Tais cenas produzem um material tão rico, que, logo em seguida, mídias de todo o mundo exibem as imagens, auxiliando na propagação do Femen e suas causas.

As imagens gravadas pelas integrantes servem como registro "oficial" da preparação e da ação em si. A página do Facebook do grupo, Femen International, traz quase a totalidade desse material, embora se note, ali, que alguns dos vídeos mais polêmicos produzidos tenham sido censurados. É o caso, por exemplo, do vídeo (Coletivo Femen) feito no dia 17 de agosto de 2012, realizado com o intuito de dar suporte às participantes do Pussy Riot, que estavam para ser julgadas durante aqueles dias na Rússia.

O vídeo mostra uma das integrantes mais ativas do grupo, Inna Shevchenko, com uma serra elétrica cortando uma cruz de madeira com a imagem de Cristo, em Kiev, capital da Ucrânia. A cruz exposta em praça pública era uma homenagem às vítimas da ditadura de Stalin e da fome dos anos 30. Já o alvo da ação, realizada em poucos minutos, era a Igreja. Os registros do vídeo mostram a presença da mídia no local e também transmitem a tensão por trás da ação que denegria um objeto cuja simbologia transcende o significado local. Ao espectador desavisado, restava perguntar-se sobre o seu intuito.

Em depoimento sobre a ação, Anna Hutsol explica-o dessa maneira:

On the day of the sentencing, the Femen women's movement expresses its support and respect for its 
${ }^{25}$ No dia da sentença, o movimento de mulheres Femen expressa seu apoio e respeito às suas colegas russas do grupo Pussy Riot [... Através desse ato, o Femen chama todas as forças saudáveis da sociedade para serrar para fora de suas cabeças todo o preconceito religioso podre que serve como base para a ditadura e que impede o desenvolvimento da democracia e da liberdade das mulheres. [Tradução própria]

${ }^{26}$ Neste caso, a referência é ao filme O Massacre da Serra Elétrica (1974). Uma charge que faz essa relação direta entre a ação e o filme, intitulada "Ukranian Chainsaw Massacre", está disponível em: http://theunfriendlyatheist.tumblr. com/post/3040881 1840/zombiejesuses-lol.

27 Estupre-me. Eu sou imoral. [Tradução própria]

${ }^{28}$ Nós temos mãos para parar o estupro. [Tradução própria]
Russian colleagues from the group Pussy Riot. [...] By this act, Femen calls on all healthy forces of society to mercilessly saw out of their heads all the rotten religious prejudice that serves as a foundation for dictatorship and prevents the development of democracy and women's freedom (FEMEN, 2012). ${ }^{25}$

Os elementos estratégicos anteriormente citados se fazem presentes novamente nessa ação. Inna, uma mulher loira, exuberante e seminua, apodera-se de um instrumento masculino, violento e cinematograficamente reconhecível ${ }^{26}$ para destruir um símbolo religioso. De forma análoga à ação do Pussy Riot, esse vídeo do Femen é significativo por provocar uma espécie de curto-circuito na percepção humana a respeito de uma iconografia previamente conhecida, mas utilizada de forma completamente diversa. Uma bela mulher assume o comando de uma serra elétrica, nos moldes de um filme trash, de terror, aos pés de uma clássica cruz cristã de madeira. Três elementos díspares unidos com o intuito único de provocar.

Nesse sentido, essa ação em particular e o Femen, de forma mais generalizada, mostram que o grupo tem conseguido explorar elementos contemporâneos da imagem que o colocam, hoje, em situação de destaque. Em diálogo com o pós-moderno, as ações do grupo fundem elementos, nivelando-os sem um critério muito claro. Ao atuarem dessa maneira, proporcionam uma aproximação com a audiência que, por sua vez, tem a chance de fazer a interpretação que mais lhe convier, considerando condições locais e globais de relação com as características daquelas imagens.

Essa estratégia do grupo em fundir elementos imagéticos - em princípio díspares - pode ser notada, também, na ação do dia 03 de outubro de 2012, tendo como alvo, desta vez, uma obra de arte. Nesse dia, o Femen esteve no Museu do Louvre para "tomar" por alguns momentos a estátua da Vênus de Milo. O intuito era protestar contra a violação de uma mulher por policiais, na Tunísia, quando estes a encontraram com o namorado numa "posição imoral". Apesar do acontecido, a mulher e o namorado ainda respondem por "atentado ao pudor" no país.

$\mathrm{Na}$ estátua foi colocado um cartaz em que se lia "Rape me, l'm immoral", ${ }^{27}$ enquanto as ativistas, de seio aberto e com frases de ordem pintadas em seus corpos, gritavam "we have hands to stop rape", ${ }^{28}$ que se tornou o slogan do novo protesto. O mesmo segue com um apelo que se apoia na iconicidade das obras de arte, por meio de estratégias de colagem e releitura de algumas obras.

Nesses dois exemplos, notamos que a materialidade do corpo feminino em situação de risco cria uma atmosfera que é, ao mesmo tempo, real e fictícia, tornando essa 
${ }^{29}$ Sua intervenção discursiva pode estar mais nos hiperpúblicos que projetam nas ruas e online, com sua narrativa de protesto continuamente modificada pelas participantes. Nesse entendimento do grupo, a linha entre ficção e realidade é conscientemente manipulada. [Tradução própria]

${ }^{30}$ Trecho original: "the media tends to pick out the performative precisely because the performative stages the dramas that the media considers to be the news". [Tradução própria] separação difícil de ser definida. Apesar das prisões e do risco corporal serem reais, a ação do Femen é tão performática e entrelaçada com outros elementos do mundo da ficção, que permite a ativação dos sentidos, despertando afetos ao mesmo tempo oníricos, desejantes e políticos. Nas palavras de Zychowicz:

Their discursive intervention may lie more in the hyperpublics they design on the streets and online, with their protest narrative continually modified by participants. In this understanding of the group, the line between fiction and reality is consciously manipulated $\left(2011\right.$, p. 223). ${ }^{29}$

Com relação a essa característica do grupo, que funde a ficção e a realidade, Baz Kershaw (1999) nos lembra de que a performance é uma arte que traz em si um forte caráter político, pois, quando vinculada a uma ação de protesto público, é capaz de trazer elementos estéticos com potencial para corromper padrões de significados que compõem o simulacro. Como são ações que costumam chamar a atenção da grande mídia, as ações performáticas inseridas nos espaços públicos e midiáticos contribuem para esse rompimento, pois carregam em si um potencial para a desordem. Como nos coloca o autor, "a mídia tende a selecionar o performativo precisamente porque o performativo encena os dramas que a mídia considera serem as notícias" (KERSHAW, 1999, p. 98 [Tradução própria]). ${ }^{30}$

Ao assim fazê-lo, a grande mídia contribui para a desconstrução das narrativas dominantes por entender o protesto como pauta relevante. No caso do Femen, o grupo joga justamente nesse cenário, pois, independentemente das razões dos editores, variando da militância ao sensacionalismo, as performances do grupo sempre parecem ser motivo de pauta.

\section{A biopolítica do feminino}

Ao clamarem por uma liberdade de "fazer o que se quer com o corpo", as ativistas dos exemplos acima citados procuram derrubar instituições como o patriarcalismo, a polícia, o governo e a lgreja, por entenderem que as mesmas oprimem o corpo feminino. Por meio das estratégias que analisamos, elas esteticizam os principais elementos da sociedade de controle, convidando-os, involuntariamente, a participar desse jogo.

Na ação de Aliaa Magda Elmahdy, notamos como a imagem amadora que usa o corpo feminino como forma de protesto foi capaz de provocar um debate que questionava justamente o grau de liberdade a que estaria submetida a prometida democracia no Egito. Por meio da "individualização" da política feita através da utilização da imagem do 
corpo, o caso mostra a fusão entre o debate local e as novas instâncias de significado geradas com o compartilhamento da imagem nas redes de comunicação digital.

Já com os acontecimentos envolvendo a banda Pussy Riot, o que procuramos desconstruir foi a ideia de que os vídeos eram fatos isolados produzidos por um grupo de meninas dissidentes. As manifestações da banda têm base, como mostramos, em outros movimentos de cultura pop, principalmente o punk-rock e o $D / Y$, além de serem resultado de um movimento maior de um ativismo debochado e radical presente hoje na Rússia. Notadas essas particularidades, o exemplo demonstra novamente as amarrações existentes entre a produção de imagens amadoras, sua reutilização nas redes e o potencial para a geração de debates que questionam o poder tradicional que luta para entender qual a lógica dessa nova política feita por meio das redes sociais.

Finalmente, no caso do Femen, as participantes arriscam-se num discurso de liberdade que pressupõe corpos perfeitos. Nesse aspecto, quando falam na "opção" de serem o que quiserem ser, trabalham com a questão éticopolítica apontada por Rose (2011), em que há um alinhamento entre os desejos dos sujeitos e sua subjetividade e as políticas de regulamento da saúde da população. A politização dos corpos, preenchidos com frases de ordem, é uma metáfora da exigência das demandas dos sujeitos por sua "existência biológica", como nos coloca Rose.

O mesmo acontece com os outros dois exemplos. Com Aliaa, a existência biológica (o seu corpo) é a própria política. Expô-la da forma como apresentamos gerou o debate em torno da imagem produzida pela ativista. No caso do Pussy Riot, há uma vontade de transformação que coloca a "existência biológica" em situações de perigo a fim de criar imagens que provoquem o poder por meio da interferência corporal, muitas vezes inusitada, em locais politicamente significativos. Em todos os casos, observamos alguns elementos em comum que os unem e que explicam o fato de terem se tornado exemplos da utilização de imagens amadoras como forma de fazer política no mundo contemporâneo por meio de sua exploração nas redes digitais de comunicação.

O primeiro desses elementos é, obviamente, a questão feminina, significativa para nossos questionamentos, nesse trabalho, por mostrar que as ferramentas de comunicação digital proporcionam a maior abertura para o debate de micropolíticas emergentes. Isso fica bem claro com os exemplos, pois partem de demandas locais, de questões privadas e de gênero.

Quando se observa a história do feminismo e suas formas de fazer protestos em forma de arte, notamos uma 
forte participação da exposição do corpo. Como vimos em Carlson (2009), essa era uma estratégia que tinha, em linhas gerais, o objetivo de colocar o corpo feminino dentro de uma perspectiva, que não aquela do sujeito passivo e coadjuvante predominante nas sociedades patriarcais. Expor o corpo é, também, uma forma de trazer questões de cunho privado para o político e, nesse sentido, as ações das ativistas alinham-se com as causas feministas das últimas décadas. Como nos coloca Lucila Scavone:

Considerar as questões pessoais como questões políticas foi - e é - um dos grandes avanços e contribuições do feminismo contemporâneo à análise das relações sociais, pois este princípio evidenciou que as desigualdades entre os sexos só poderiam ser compreendidas (e superadas) se fossem, também, consideradas as relações de dominação e poderes que se constroem no espaço privado (2004, p. 30).

O que consideramos relevante destacar é que, neste momento em que analisamos esses casos, existe uma potencialização dos recursos estéticos proporcionada pela disseminação, autorreferenciação e releituras das imagens reproduzidas nas redes sociais.

Todos os exemplos trazem, também, características que remetem a uma cultura pop compartilhada globalmente. $O$ fato é bastante relevante para entendermos como a análise dessas imagens passa, igualmente, por um processo de produção de cultura que funde o local com o global. Scott Lash e John Urry (1996) já anunciavam um chamado "capitalismo desorganizado", provocado pela falta de um centro de referência que fosse capaz de servir de mecanismo único do comportamento do sistema. Isso causaria o desenvolvimento simultâneo de duas culturas: uma cultura global, dividida entre territórios diversos, e uma cultura local, resultante das forças que ainda operam em cada um dos territórios. Imagens advindas dos mais diversos cantos do mundo misturam-se e hibridizam-se com imagens locais. Isso provoca, na opinião dos autores, o surgimento de culturas particulares.

Nos casos que analisamos, esse fato é bastante evidente. As mesmas imagens criadas por essa "cultura particular" (o ativismo feminista digital e amador) têm diferentes significados - a depender de onde são consumidas. Ao mesmo tempo, possuem referências tanto locais como globais que as auxiliam a construir narrativas de manifestação política.

Há vários componentes que indicam essa alusão a uma cultura pop compartilhada. O primeiro deles é o próprio fetiche ligado ao corpo feminino. Uma ampla gama de 
referências pode ser listada quando observamos algumas das estratégias propostas, principalmente pelo Femen, mas também presentes no caso de Aliaa. Para mencionar apenas alguns desses fetiches, algumas das indumentárias e fotografias do Femen remetem aos desenhos de pin-ups, à sexualidade misturada aos filmes de terror e à violência fetichizada da luta entre mulheres seminuas e homens de farda, esta presente, principalmente, nas fotografias tiradas em espaços públicos com intervenção real da polícia local. No caso de Aliaa, notamos uma inspiração na Pop-Art, pela escolha de destacar apenas uma cor que faz sobressair alguns detalhes da fotografia em preto e branco. Além disso, a pose é uma pose clássica de pinturas de nu feminino, nas quais se nota, também, apenas um banquinho que serve de apoio à modelo.

Outras referências são o rock, a cultura DIY (Pussy Riof) e as alusões ao cinema e a obras de arte (Femen). Elas dialogam com as imagens analisadas e ganham importância se lembrarmos que o objetivo dessas ações é causar impacto para além das fronteiras dos países de origem das ativistas. A referência global é, portanto, uma estratégia de ação, como também já analisado por Bennett (2003) e Henry Jenkins (2009).

\section{Conclusões}

Este trabalho destacou a presença de ações ativistas feministas que se utilizam do uso do corpo, da performance e do radicalismo para explorar as potencialidades de comunicação oferecidas pelas redes sociais. Mostrou, também, o viés sombrio dessa exposição da vida nua em forma de política digital e global, pois traduz uma politização do privado e do individual que não só atende a demandas oriundas dos desejos e frustrações dos indivíduos conectados pelo mundo, mas que ultrapassa as barreiras dessa comunicação alternativa, atingindo, também, as grandes corporações midiáticas.

Esse movimento pode ser um indício que, mesmo em se tratando de atos de protestos surgidos de forma espontânea, são fruto de uma resposta às forças biopolíticas que operam na sociedade e, ao tentar significar um contrário, acabam dialogando com o próprio sistema, o que justifica, sobretudo, sua rápida absorção pelo jornalismo corporativo e, também, pelas mídias digitais. Se existe uma nova política sendo feita por meio das redes sociais, ela está centrada em demandas de cunho vital, e, portanto, não necessariamente novas e, se revolucionárias, são, ainda assim, fruto de uma política centrada em demandas privadas e individuais em que se preza o direito à vida e à liberdade de expressão. 


\section{Referências}

AGAMBEN, Giorgio. Homo Sacer: o poder soberano e a vida nua. Belo Horizonte: UFMG, 2007.

BARTON, Laura. "Pussy Riot's Kremlin protest owes much to riot grrl". The Guardian, 03/02/2012. Disponível em: http:// www.guardian.co.uk/commentisfree/2012/feb/03/pussyriot-kremlin-protest-riot-grrrl. Acesso em: 22 jan. 2016.

BENNET, Lance W. "New Media Power: the internet and global activism". In: COULDRY, Nick; CURRAN, James (Eds.). Contesting Media Power: alternative media in a networked world. Oxford: Rowman \& Littlefield Publishers, 2003.

CARLSON, Marvin. Performance: uma introdução crítica. Belo Horizonte: UFMG, 2009.

COLETIVO Femen. Topless Protester Cuts Down Cross in Kiev. Disponível em: http://www.liveleak.com/view?i=034_134 5223473. Acesso em: 27 ago. 2015.

COLETIVO Voina. Dick Captured by the FSB. São Petersburgo, 14/06/2010. Disponível em: http://www.youtube.com/ watch? $\mathrm{v}=\mathrm{kMXQ3U} 3 \mathrm{FSy}$ \&feature $=$ channel_video_title. Acesso em: 22 jan. 2016.

. Fuck for the heir Puppy Bear! Moscou, 29/02/2008. Disponível em: http://www.liveleak.com/view?i=a4d_120 4458756. Acesso em: 22 jan. 2016.

CORPS et Âmes. Direção: Jean-Baptiste Mondino, 2012. Disponível em: https://www.youtube.com/watch?v=eCC wFiucjm0. Acesso em: 22 jan. 2016.

DABASHI, Hamid. "La vita nuda: Baring bodies, bearing witness". Aljazeera, 23/01/2012. Disponível em: http:// www.aljazeera.com/indepth/opinion/2012/01/ 201212111238688792.html. Acesso em: 22 jan. 2016.

DAWKINS, Richard. The Selfish Gene. New York: Oxford University Press, 2006.

ELMAHDY, Aliaa Magda. Nude art. Cairo, 23/10/2011. Disponível em: http://arebelsdiary.blogspot.com.br/2011/ 10/nude-art 2515.html.

"Egyptian blogger Aliaa Elmahdy: Why I posed naked". CNN online, 20/11/2011. Entrevista concedida a Mohamed Fadel Fahmy. Disponível em: http:// edition.cnn.com/201 1/1 1/19/world/meast/nude-bloggeraliaa-magda elmahdy/index.html?hpt=hp_ł. Acesso em: 22 jan. 2016.

FARAHANI, Golshifteh. Madame Le Figaro, 2012. Disponível em: http://25.media.tumblr.com/tumblr_ly273xRmUx1 qlb nzqo1_500.jpg. Acesso em: 21 jan. 2016.

FEMEN activists cut down cross in Kyiv. Radio Free Europe, 17/08/2012. Disponível em: http://www.rferl.org/content/ ukraine-femen-cross-pussy-riot/24679942.html. Acesso em: 20 jan. 2016. 
FEMEN INTERNATIONAL. Disponível em: https://www.facebook. com/FEMEN.International.Official. Acesso em: 30 set. 2015.

FOUCAULT, Michel. História da Sexualidade 1: a vontade de saber. Rio de Janeiro: Graal, 1988. 2008

. Nascimento da biopolítica. São Paulo: Martins Fontes,

GUERRILA Girls. 1985-2016. Disponível em: http:// www.guerrillagirls.com. Acesso em: 22 jan. 2016.

GOLDBERG, Vicki. The power of photography: how photographs changed our lives. New York: Abbeville Press, 1991.

JENKINS, Henry. Cultura da Convergência. São Paulo: Aleph, 2009.

KILLKENNYKAT. Ukrainian chainsaw massacre, 08/2012. http:/ /theunfriendlyatheist.tumblr.com/post/30408811840/ zombie-jesuses-lol. Acesso em: 22 jan. 2016.

LANGSTON, Henry. "Meeting Pussy Riot". Vice, 2012. Disponível em: http://www.vice.com/read/A-Russian-Pussy-Riot. Acesso em: 19 jan. 2016.

LASH, Scott; URRY, John. Economies of Signs and Space. London: Sage Publications, 1996.

KERSHAW, Baz. The Radical in Performance. London: Routledge, 1999.

MASSACRE da serra elétrica, O. Direção: Tobe Hooper. EUA, 1974. Terror. 83 min. Roteiro: Kim Henkel, Tobe Hooper. Elenco: Allen Danziger, Edwin Nael, Gunnar Hansen, Jim Siedow, John Dugan, Marilyn Burns, Paul A. Partain, Teri McMinn, William Vail. Produção: Tobe Hooper. Fotografia: Daniel Pearl. Trilha Sonora: Tobe Hooper, Wayne Bell.

MESQUITA, André. Insurgências Poéticas: Arte Ativista e Ação Coletiva (1990-2000). 2008. Dissertação (Mestrado em História Social) - Programa de Pós-Graduação em História, Faculdade de História, Universidade de São Paulo, São Paulo.

MICHAEL, Maggie. "Egypt activist posts herself nude, sparks outrage". The Guardian, 17/1 1/201 1. Disponível em: http:/ /www.guardian.co.uk/world/feedarticle/9952436. Acesso em: 07 nov. 2012.

NEUFELD, Dialika. "Getting Naked to Change the World". Spiegel online, 11/05/2012. Disponível em: http:// www.spiegel.de/international/europe/femen-activistsget-naked-to-raise-political-awareness-a-832028.html. Acesso em: 21 jan. 2016.

PUSSY Riot - A Punk Prayer. Direção: Maxim Pozdorovkin e Mike Lerner. Reino Unido da Grã Bretanha, Rússia, e Irlanda do Norte, 2013. Documentário. 90 min. Intérpretes: Maria Alyokhina, Nadezhda Tolokonnikova e Yekaterina Samutsevich. 
Pussy Riot gig at Christ the Savior Cathedral. Moscou, 2012. Disponível em: http://www.youtube.com/ watch? $v=$ grEBLskpDWQ. Acesso em: 22 jan. 2016.

. Pussy Riot Red Square. Moscou, 2012. Disponível em: http://www.youtube.com/watch?feature=player_em bedded\&v=7kVMADLm3js. Acesso em: 22 jan. $201 \overline{6}$.

Revolt in Russia, Putin's got scared, 2011 . Disponível em: http://russmus.net/song/12000. Acesso em: 22 jan. 2016.

RIOT Grrrl. Riot Grrrl Manifesto. Bikini Kill Zine, EUA, 1991. Disponível em: http://onewarart.org/riot_grrrl_manifesto.htm. Acesso em: 22 jan. 2016.

ROSE, Nikolas. "The politics of life itself". Theory, Culture and Society, Thousand Oaks London and New Delhi, v. 18, n. 6, p. 1-30, 2001.

RUMENS, Carol. "Pussy Riot's Punk Prayer is pure protest poetry". The Guardian, United Kingdom, 20/08/2012. Disponível em: http://www.guardian.co.uk/books/2012/aug/20/ pussy-riot-punk-prayer-lyrics. Acesso em: 22 jan. 2016.

SANTAELLA, Lúcia. Corpo e Comunicação: sintomas da cultura. São Paulo: Paulus, 2004.

. "A estética política das mídias locativas". Nómadas, Colômbia, n. 28, Universidad Central, 28 de abr. 2008.

SCAVONE, Lucila. Dar a vida e cuidar da vida: feminismo e ciências sociais. São Paulo: UNESP, 2004.

STUHR-ROMMEREIM, Helen. "Pussy Riot in Translation". Full Stop blog, 17/08/2012. Disponível em: http://www.full-stop.net/ 2012/08/1 7/blog/helen-stuhr-rommereim/pussy-riot-intranslation/. Acesso em: 19 jan. 2012.

ZYCHOWICZ, Jessica. "Two Bad Words: FEMEN \& Feminism in Independent Ukraine". Anthropology of East Europe Review, Leste europeu, Rússia, Bálcãs e Ásia Central, v. 29, n. 2, p. 215-227, 2011.

[Recebido em 04/09/2013, reapresentado em 22/01/2016 e aceito para publicação em 13/04/2016]

Biopolitics of Female Body in Contemporary Strategies of Digital Activism Abstract: In this work, it is observed the use of female body image as a repeated strategy in activist actions in different parts of the world. The aesthetic-political elements of the body, which have historically been used by the Arts, such as nudity, pain, eroticism and identity (or anonymity), are redirected to an active and participative culture project in the digital communication networks. The analysis is located in the biopolitics field and makes use of three recent examples: the Egyptian Aliaa Magda Elmahdy self-portraits and the actions of the collectives Pussy Riot (Russia) and Femen (Ukraine).

Key words: Female Body; Biopolitics; Digital Activism; Pussy Riot; Femen. 